\title{
Effect of Foliar Application of Zinc and Boron on Growth and Yield of Mungbean (wilczek) (Vigna radiata $\mathrm{L}$.
}

\author{
Narendra Pratap Verma ${ }^{1}$, M. A. Khan ${ }^{2}$, Pradip Kumar Saini ${ }^{1 *}$, \\ Virendra Pratap Verma ${ }^{3}$ and Shraddha Singh ${ }^{1}$
}
${ }^{I}$ Department of Crop Physiology, Acharya Narendra Deva University of Agriculture \& Technology, Kumarganj, Ayodhya-224229 (U.P.), India
${ }^{2}$ Department of Crop Physiology, Chandra ShekharAzad University of Agriculture \& Technology, Kanpur- 208002 (U.P.), India
${ }^{3}$ Department of Agronomy Narain College Shikohabad, Firozabad (U.P.), India

*Corresponding author

\section{A B S T R A C T}

\begin{tabular}{l} 
K e y w o r d s \\
$\begin{array}{l}\text { Mungbean, Zinc, } \\
\text { Boron, Growth and } \\
\text { Yield }\end{array}$ \\
\hline Article Info \\
$\begin{array}{l}\text { Accepted: } \\
\text { 26 September } 2020 \\
\text { Available Online: } \\
10 \text { October } 2020\end{array}$
\end{tabular}

A Pot experiment was carried out entitled "Effect of foliar application of Zinc and Boron on growth and yield of Mungbean" (wilczek) (Vigna radiata L.) during Kharif season 2018 in the wire net house in pot in the Department of Plant Physiology, C. S. Azad University of Agriculture \& Technology, Kanpur. The experiment consisted 7 treatments viz. $\mathrm{T}_{1}$ : Control, $\mathrm{T}_{2}: \mathrm{Zn} @ 50 \mathrm{ppm}, \mathrm{T}_{3}: \mathrm{Zn} @ 100 \mathrm{ppm}, \mathrm{T}_{4}: \mathrm{Zn} @ 150 \mathrm{ppm} \mathrm{T}$ : B @ 100ppm, $\mathrm{T}_{6}$ : @ B 200ppm and $\mathrm{T}_{7}$ : @ B 300ppm assigned in CRD with five replication during kharif season of 2018. The mungbean cv. Samrat was used in the experiment. The soil of the experimental plot was sandy loam in texture, medium in fertility and slightly alkaline in reaction. The weather during the experimental period was by and large normal and devoid of any extreme conditions. The results indicated that application of $\mathrm{T}_{7}$ : $\mathrm{B} @ 300 \mathrm{ppm}$ resulted in significantly maximum plant height, No. of Pods plant ${ }^{-1}$, number of seed Pods ${ }^{-1}$, No. of seed Plant ${ }^{-1}, 1000$ - seed weight $(\mathrm{g})$ and ultimately higher seed yield $(\mathrm{g})\left(\mathrm{Plant}^{-1}\right)$ as compared to other corresponding tested treatments. The treatment is also excellent under B @ 300ppm.

\section{Introduction}

Green gram locally called as moong or mung [Vigna radiata $\mathrm{L}$.) It belongs to the family leguminaceae so it has the capacity to fix atmospheric nitrogen. It's one of the important kharif pulse crops of India which can be grown as catch crop between rabi and kharif seasons. India alone accounts for $65 \%$ of its world acreage and $54 \%$ of the total production. It is grown on about $3.50 \mathrm{~m}$ ha in the country mainly in Rajasthan, Maharashtra, Andhra Pradesh, Karnataka, Orissa and Bihar. A phenomenal increase in area, production and productivity has occurred since 1964-65. The area has increased from 1.99 million ha in 1964-65 to 3.54 million ha in 2010-2011. The production has increased from 0.60 million tonnes to 1.81 million tonnes during the same period. Throughout the India, the 
mungbean issued for different purposes. The major portion is utilized in making dal, soup, sweets and snacks. Mungbean is an excellent source of protein $(25 \%)$ with high quality of lysine (460 $\mathrm{mg} \mathrm{g}^{-1}$ ) and tryptophan $\left(60 \mathrm{mg} \mathrm{g}^{-}\right.$ $\left.{ }^{1}\right)$. It also has remarkable quantity of ascorbic acid when sprouted and also have riboflavin $\left(021 \mathrm{mg} 100 \mathrm{~g}^{-1}\right)$ and minerals (3.84 W $100 \mathrm{~g}^{-}$ $\left.{ }^{1}\right)$. The total area under pulses is $23.63 \mathrm{~m}$ ha with an annual production of $14.76 \mathrm{M}$ tonnes in the country. In India green gram occupies 3.4 million hectare area and contributes to 1.4 million tonnes in pulse production. Mungbean contributes $14 \%$ in total pulse area and $7 \%$ in total pulse production in India.

The low productivity of mungbean may be due to nutritional deficiency in soil and imbalanced external fertilization. Micronutrients are essential for plant growth; Zinc is one of the seven pillars of nutrition and is needed for the growth of plant, animals and humans. The amount of zinc in pasture and forage is very little and varies from 20 to $30 \mathrm{mg} \mathrm{kg}{ }^{-1}$ in soil. Zinc is necessary to activate many enzymes, enzymes that are activated by the zinc are Tryptophan synthetase superoxide dismutase and dehydrogenases. Lack of zinc causes deficiency in formation of RNA and protein. Therefore, the plant with lack of zinc is poor in amount of protein. Foliar spraying of micronutrients for the growth of greengram and its quality in industry views is necessary for growth and quality of greengram.

Micronutrients like boron is one of the mineral nutrients required for normal plant growth. The most important functions of boron in plants are thought to be its structural role in cell wall development, cell division, seed development and stimulation or inhibition of specific metabolic pathways for sugar transport and hormone development. Furthermore, boron deficiency causes decrease in pollen grain count, pollen germination etc. It also influences growth parameters and filling up of seeds. It is usually accepted that boron availability is decreased under dry soil conditions.

Thus, boron deficiency is often associated with dry weather and low soil moisture conditions. This behaviour may the related to restricted release of boron from organic complexes which ultimately impaired ability of plants to extract B from soil due to lack of moisture in the rhi7osphere. Even of B levels in soil is high, then also low soil moisture impairs transport of $\mathrm{B}$ to absorbing root surfaces (Das et al., 2016).

\section{Materials and Methods}

The field experiment was conducted in the pot culture during Kharif season 2018 in the wire net house in pot in the Department of Plant Physiology, C. S. Azad University of Agriculture \& Technology, Kanpur. Geographically, the site of experiment is situated at Latitude of $80^{\circ}, 24^{\circ}$ East and an Altitude 127 meter above mean Sea level in Genetic Alluvium soil in summer and severe cold winter. The experiment was conducted in complete randomized design with 7 treatment and 5 replications. The seed of mungbean variety of Samrat (PDM 139) were obtained from seed processing farm IIPR Kanpur. The experiment consisted treatments viz. $\mathrm{T}_{1}$ : Control, $\mathrm{T}_{2}: \mathrm{Zn} @$ 50ppm, $\mathrm{T}_{3}: \mathrm{Zn} @ 100 \mathrm{ppm}$, $\mathrm{T}_{4}: \mathrm{Zn} @ 150 \mathrm{ppm} \mathrm{T}_{5}: \mathrm{B} @ 100 \mathrm{ppm}, \mathrm{T}_{6}$ : @ B 200ppm and $\mathrm{T}_{7}$ : @ B 300ppm assigned in CRD with five replication during kharif season of 2018. Growths and Yields Parameter viz. Height /plant $(\mathrm{cm})$, No. of leaves/plant, Leaf area/plant $\left(\mathrm{cm}^{2}\right)$, Relative growth rate (RGR) (mg/g/day), Total dry matter production $(\mathrm{g})$, No. of branches/plant and No. of pods/plant, No. of seeds/pod, No. of seed/Plant, Seed weight/plant (g), 1000 seed weight $(\mathrm{g})$. 


\section{Results and Discussion}

\section{Plant height}

The data recorded on plant height and the result is given in Table 1, and depleted in Fig. 1. It is clear from the data that plant height was increasing with increasing days after sowing. The height was remarkably increased in between 25 to 50 days after sowing and significant differences were observed at all stages of crop growth. The tallest plants were observed in the treatment of $\mathrm{T}_{7}$ with application of B @ 300ppm followed by $\mathrm{T}_{4}$ $\mathrm{Zn} @ 150 \mathrm{ppm}$, whereas minimum values were obtained in control. In 25 DAS treatment B @ 300ppm was found to be highest plant height $(18.47 \mathrm{~cm})$ statistically superior and at par to treatment Zn @ 50ppm, Zn@100ppm,Zn@150ppm, B @ 100ppm, B @ 200ppm. Minimum plant height was obtained in control $(13.75 \mathrm{~cm})$. At 50 DAS treatment B @ 300ppm was found to be highest plant height $(36.38 \mathrm{~cm})$ statistically superior and at par to treatment Zn @ 100ppm, Zn@150ppm, Zn@ @ $@$ ppm, B @ 100ppm, B @ 200ppm. Minimum plant height was obtained in control $(31.26 \mathrm{~cm})$. At Maturity treatment B @ 300ppm was found to be highest plant height $(37.52 \mathrm{~cm})$ statistically superior and at par to treatment Zn @ 150ppm,Zn@100ppm, B @ 200ppm, Zn @ 50ppm, B @ 100ppm. Minimum plant height was obtained in control $(32.40 \mathrm{~cm})$ (Salinas et al., 1985).

\section{No. of leaves plant ${ }^{-1}$}

The data on No. of leaves plant ${ }^{-}$and the result is given in Table 2 and depleted in Fig. 2. The data clear indicate that number of leaves plant $^{-1}$ was significantly affected due to different treatments. It increased up to 50 days after sowing thereafter at maturity substantial reduction was observed. The maximum value is found it $\mathrm{T}_{7} \mathrm{~B} @ 300 \mathrm{ppm}$.
The lowest and highest values were observed in control and $\mathrm{T}_{1}$ : Control, respectively. At 25 DAS treatment Zn @150ppm was found to be highest no ofleavesplant ${ }^{-1}$ (13.85) statistically superior and at par to treatment B @ 300ppm, Zn@100ppm, B @ 200ppm, Zn @ 50ppm followed by B @ 100ppm. Minimum no of leaves plant ${ }^{-1}$ was obtained in control (9.85). At 50 DAS treatment Zn @ $150 \mathrm{ppm}$ was found to be highest no of leaves plant $^{-1}$ (19.90) statistically superior and at par to treatment B @ 300ppm, Zn @ 100ppm, B @200ppm followed by Zn @ 50ppm, B @ $100 \mathrm{ppm}$. Minimum no of leaves plant ${ }^{-1}$ was obtained in control (14.15). At Maturity treatment B @ 300ppm was found to be highest no of leaves plant ${ }^{-1}$ (20.76) statistically superior and at par to treatment Zn@150ppm, Zn @ 100ppm, B @ 200ppm followed by Zn @ 50ppm, B @ 100ppm. Minimum no of leaves plant ${ }^{-1}$ was obtained in control (15.55).

\section{Leaf area}

The data on Leaf area and the result is given in Table 3 and depleted in Fig. 3. It is obvious from the data that Leaf area were significantly affected due to different treatments. Leaf area 1 were substantially increased up to maturity. The maximum were recorded in the treatment of $\mathrm{T}_{7} \mathrm{~B} @ 300 \mathrm{ppm}$. The control treatment showed minimum Leaf area notwithstanding, the increasing trend was observed with increasing doses of foliar application. AT 25 DAS treatment B @ 300ppm was found to be highest leaf area (161.52) statistically superior and at par to treatment Zn @ 150ppm followed by Zn @ 100ppm, B @ 200ppm, Zn @ 50ppm, B @100ppm. Minimum leaf area was obtained in control (139.35). AT 50 DAS treatment B @ 300ppm was found to be highest leaf area (621.50) statistically superior and at par to treatment $\mathrm{Zn} \mathrm{@} \mathrm{150ppm}$ followed by Zn @ 100ppm, B @ 200ppm, Zn @ 50ppm, B @100ppm. Minimum leaf area 
was obtained in control (536.75). At Maturity treatment B @ 300ppm was found to be highest leaf area (969.74) statistically superior and followed by Zn @ 150ppm, Zn @ 100ppm, B@ @200ppm, Zn @ 50ppm, B @ 100ppm. Minimum leaf area was obtained in control (837.45) (Shamsuddoha et al., 2011).

\section{Relative Growth Rate}

The data on Relative Growth Rate and the result is given in Table 4, and depleted in Fig. 4. The critical examination of the data reveal that thickest plants were observed in the treatment of $\mathrm{T}_{7}$ when $\mathrm{B} @ 300 \mathrm{ppm}$ was applied as compared to minimum relative growth rate in control at all stages of crop growth. The relative growth rate was increasing up to 50 DAS to at maturity thereafter rate of growth become slower in all the treatments. 25 DAS to 50 DAS treatment B @ 300ppm was found to be highest relative growth rate (32.59) statistically superior and at par to treatment Zn @ 150ppm followed by Zn@100ppm, B@200ppm Zn@ @0ppm, B @ 100ppm. Minimum relative growth rate was obtained in control (28.15). 50 DAS to Maturity treatment B @ 300ppm was found to be highest relative growth rate (16.73) statistically superior and at par to treatment Zn@150ppm, Zn@100ppm, B @ 200ppm followed by Zn @ 50ppm, B @ 100ppm. Minimum relative growth rate was obtained in control (14.44) (Patra et al., 2009).

Table.1 Effect of plant height $(\mathrm{cm})$ under different treatments

\begin{tabular}{|c|c|c|c|}
\hline \multirow[t]{2}{*}{ Treatments } & \multicolumn{3}{|c|}{ Plant heights (cm) } \\
\hline & 25 DAS & 50 DAS & At maturity \\
\hline $\mathrm{T}_{1}$ : Control & 13.75 & 31.26 & 32.40 \\
\hline $\mathrm{T}_{2}: \mathrm{Zn}$ 50ppm & 17.24 & 33.95 & 35.09 \\
\hline$T_{3}: Z n$ 100ppm & 17.73 & 35.12 & 36.26 \\
\hline $\mathrm{T}_{4}: \mathrm{Zn} \mathrm{150ppm}$ & 18.27 & 35.99 & 37.13 \\
\hline$T_{5}:$ B 100ppm & 17.00 & 33.49 & 34.63 \\
\hline$T_{6}:$ B 200ppm & 17.58 & 34.64 & 35.78 \\
\hline$T_{7}:$ B 300ppm & 18.47 & 36.38 & 37.52 \\
\hline $\mathrm{SE} \pm(\mathrm{d})$ & 1.45 & 1.67 & 1.71 \\
\hline CD at $(0.05 \%)$ & 2.66 & 3.25 & 3.34 \\
\hline
\end{tabular}

Table.2 Effect of No. of leaves plant ${ }^{-1}$ under different treatments

\begin{tabular}{|c|c|c|c|}
\hline \multirow[t]{2}{*}{ Treatments } & \multicolumn{3}{|c|}{ No. of leaves plant ${ }^{-1}$} \\
\hline & 25 DAS & 50 DAS & At maturity \\
\hline $\mathbf{T}_{1}:$ Control & 9.85 & 14.15 & 15.55 \\
\hline $\mathrm{T}_{2}: \mathrm{Zn} \mathrm{50ppm}$ & 12.35 & 17.74 & 19.49 \\
\hline$T_{3}: Z n$ 100ppm & 12.97 & 18.63 & 20.05 \\
\hline$T_{4}: \mathrm{Zn} \mathrm{150ppm}$ & 13.85 & 19.90 & 20.66 \\
\hline$T_{5}: B$ 100ppm & 12.25 & 17.60 & 19.22 \\
\hline $\mathrm{T}_{6}:$ B 200ppm & 12.90 & 18.53 & 19.88 \\
\hline$T_{7}:$ B 300ppm & 13.62 & 19.56 & 20.76 \\
\hline $\mathrm{SE} \pm(\mathrm{d})$ & 0.89 & 0.92 & 1.02 \\
\hline CD at $(0.05 \%)$ & 1.56 & 1.89 & 2.05 \\
\hline
\end{tabular}


Table.3 Effect of Leaf area under different treatments

\begin{tabular}{|c|c|c|c|}
\hline \multirow[t]{2}{*}{ Treatments } & \multicolumn{3}{|c|}{ Leaf area $\left(\mathrm{cm}^{2}\right)$} \\
\hline & 25 DAS & 50 DAS & At maturity \\
\hline$T_{1}$ : Control & 139.35 & 536.75 & 837.45 \\
\hline$T_{2}: Z n$ 50ppm & 150.94 & 581.38 & 907.08 \\
\hline$T_{3}: Z n$ 100ppm & 155.97 & 600.76 & 937.32 \\
\hline $\mathrm{T}_{4}: \mathrm{Zn} 150 \mathrm{ppm}$ & 159.70 & 615.14 & 959.76 \\
\hline $\mathrm{T}_{5}: \mathrm{B} 100 \mathrm{ppm}$ & 148.92 & 573.61 & 894.96 \\
\hline $\mathrm{T}_{6}:$ B 200 ppm & 153.88 & 592.71 & 924.76 \\
\hline $\mathrm{T}_{7}:$ B 300 ppm & 161.52 & 621.50 & 969.74 \\
\hline $\mathrm{SE} \pm(\mathrm{d})$ & 2.34 & 2.89 & 3.69 \\
\hline CD at $(0.05 \%)$ & 4.67 & 5.76 & 7.02 \\
\hline
\end{tabular}

Table.4 Effect of Relative Growth Rate under different treatments

\begin{tabular}{|c|c|c|}
\hline \multirow[t]{2}{*}{ Treatments } & \multicolumn{2}{|c|}{ Relative Growth Rate $\left(\mathrm{mgg}^{-1}\right.$ day $\left.^{-1}\right)$} \\
\hline & 25 to 50 DAS & 50 DAS to At maturity \\
\hline $\mathbf{T}_{1}:$ Control & 28.15 & 14.44 \\
\hline$T_{2}: Z n$ 50ppm & 30.49 & 15.66 \\
\hline$T_{3}: Z n$ 100ppm & 31.51 & 16.17 \\
\hline $\mathrm{T}_{4}: \mathrm{Zn} 150 \mathrm{ppm}$ & 32.26 & 16.56 \\
\hline $\mathrm{T}_{5}: \mathrm{B} 100 \mathrm{ppm}$ & 30.08 & 15.44 \\
\hline$T_{6}: B 200$ ppm & 31.08 & 15.96 \\
\hline$T_{7}: B 300$ ppm & 32.59 & 16.73 \\
\hline $\mathrm{SE} \pm(\mathbf{d})$ & 0.56 & 0.45 \\
\hline CD at $(0.05 \%)$ & 1.07 & 0.98 \\
\hline
\end{tabular}

Table.5 Effect of No. of Pods plant ${ }^{-1}$ under different treatments

\begin{tabular}{|c|c|c|}
\hline \multirow[b]{2}{*}{ Treatments } & \multicolumn{2}{|c|}{ No. of Pods plant ${ }^{-1}$} \\
\hline & 50 DAS & At maturity \\
\hline $\mathbf{T}_{1}:$ Control & 6.69 & 8.71 \\
\hline$T_{2}: Z n$ 50ppm & 7.49 & 10.02 \\
\hline$T_{3}: \mathrm{Zn} \mathrm{100ppm}$ & 7.77 & 10.47 \\
\hline$T_{4}: Z n 150$ ppm & 7.93 & 10.71 \\
\hline$T_{5}:$ B 100 ppm & 7.42 & 9.99 \\
\hline$T_{6}:$ B 200 ppm & 7.67 & 10.34 \\
\hline$T_{7}:$ B 300 ppm & 8.09 & 10.85 \\
\hline $\mathrm{SE} \pm(\mathrm{d})$ & 1.01 & 1.56 \\
\hline CD at $(0.05 \%)$ & 2.03 & 2.76 \\
\hline
\end{tabular}


Table.6 Effect of Leaf dry weight (g) plant ${ }^{-1}$ under different treatments

\begin{tabular}{|c|c|c|c|}
\hline \multirow[b]{2}{*}{ Treatments } & \multicolumn{3}{|c|}{ Leaf dry weight (g) plant ${ }^{-1}$} \\
\hline & 25 DAS & 50 DAS & At maturity \\
\hline $\mathrm{T}_{1}$ : Control & 1.156 & 1.245 & 2.295 \\
\hline$T_{2}: Z n 50 p p m$ & 1.330 & 1.432 & 2.641 \\
\hline$T_{3}: Z n$ 100ppm & 1.389 & 1.496 & 2.758 \\
\hline$T_{4}: \operatorname{Zn} 150$ ppm & 1.421 & 1.530 & 2.820 \\
\hline $\mathrm{T}_{5}: \mathrm{B} 100 \mathrm{ppm}$ & 1.325 & 1.428 & 2.632 \\
\hline$T_{6}:$ B 200 ppm & 1.372 & 1.478 & 2.724 \\
\hline $\mathbf{T}_{7}: \mathbf{B} 300$ ppm & 1.440 & 1.550 & 2.858 \\
\hline $\mathrm{SE} \pm(\mathrm{d})$ & 0.08 & 0.12 & 0.23 \\
\hline CD at $(0.05 \%)$ & 0.16 & 0.25 & 0.47 \\
\hline
\end{tabular}

Table.7 Effect of Dry weight of stem (g) plant ${ }^{-1}$ under different treatments

\begin{tabular}{|c|c|c|c|}
\hline \multirow[t]{2}{*}{ Treatments } & \multicolumn{3}{|c|}{ Dry weight of stem (g) plant ${ }^{-1}$} \\
\hline & 25 DAS & 50 DAS & At maturity \\
\hline $\mathbf{T}_{1}:$ Control & 0.885 & 0.979 & 1.297 \\
\hline$T_{2}: \mathrm{Zn} 50 \mathrm{ppm}$ & 1.018 & 1.126 & 1.492 \\
\hline$T_{3}: \mathrm{Zn}$ 100ppm & 1.064 & 1.177 & 1.559 \\
\hline$T_{4}: Z n 150 \mathrm{ppm}$ & 1.088 & 1.202 & 1.594 \\
\hline$T_{5}: B 100$ ppm & 1.015 & 1.123 & 1.487 \\
\hline $\mathrm{T}_{6}: \mathrm{B} 200 \mathrm{ppm}$ & 1.051 & 1.162 & 1.540 \\
\hline$T_{7}: B 300$ ppm & 1.102 & 1.219 & 1.615 \\
\hline $\mathrm{SE} \pm(\mathrm{d})$ & 0.78 & 0.83 & 0.91 \\
\hline CD at $(0.05 \%)$ & 1.67 & 1.74 & 1.89 \\
\hline
\end{tabular}

Table.8 Effect of Dry weight of whole plant ${ }^{-1}(\mathrm{~g})$ under different treatments

\begin{tabular}{|c|c|c|c|}
\hline \multirow[t]{2}{*}{ Treatments } & \multicolumn{3}{|c|}{ Dry weight of whole plant ${ }^{-1}(g)$} \\
\hline & 25 DAS & 50 DAS & At maturity \\
\hline $\mathbf{T}_{1}$ : Control & 2.201 & 2.224 & 3.603 \\
\hline $\mathrm{T}_{2}: \mathrm{Zn} \mathrm{50ppm}$ & 2.348 & 2.559 & 4.133 \\
\hline$T_{3}: Z n$ 100ppm & 2.456 & 2.673 & 4.318 \\
\hline$T_{4}: Z n 150$ ppm & 2.509 & 2.733 & 4.414 \\
\hline$T_{5}:$ B 100 ppm & 2.340 & 2.510 & 4.119 \\
\hline$T_{6}:$ B 200 ppm & 2.423 & 2.640 & 4.264 \\
\hline $\mathbf{T}_{7}: \mathbf{B} 300 \mathrm{ppm}$ & 2.542 & 2.769 & 4.473 \\
\hline $\mathrm{SE} \pm(\mathbf{d})$ & 0.36 & 0.39 & 0.67 \\
\hline CD at $(0.05 \%)$ & 1.02 & 1.23 & 1.56 \\
\hline
\end{tabular}


Table.9 Effect of No. of branches plant ${ }^{-1}$ under different treatments

\begin{tabular}{|c|c|c|c|}
\hline \multirow[t]{2}{*}{ Treatments } & \multicolumn{3}{|c|}{ No. of branches plant ${ }^{-1}$} \\
\hline & 25 DAS & 50 DAS & At maturity \\
\hline $\mathbf{T}_{1}:$ Control & 1.845 & 3.675 & 3.592 \\
\hline$T_{2}: Z n$ 50ppm & 2.116 & 3.871 & 4.097 \\
\hline$T_{3}: \mathrm{Zn} \mathrm{100ppm}$ & 2.211 & 4.045 & 4.260 \\
\hline $\mathrm{T}_{4}: \mathrm{Zn} 150 \mathrm{ppm}$ & 2.260 & 4.135 & 4.387 \\
\hline$T_{5}: B 100$ ppm & 2.109 & 3.858 & 4.084 \\
\hline $\mathrm{T}_{6}: \mathrm{B} 200 \mathrm{ppm}$ & 2.183 & 3.994 & 4.228 \\
\hline $\mathrm{T}_{7}: \mathrm{B} 300$ ppm & 2.290 & 4.190 & 4.435 \\
\hline $\mathrm{SE} \pm(\mathrm{d})$ & 0.09 & 0.15 & 0.23 \\
\hline CD at $(0.05 \%)$ & 0.20 & 0.32 & 0.48 \\
\hline
\end{tabular}

Table.10 Effect of No. of seed Pods ${ }^{-1}$ and No. of seed Plant ${ }^{-1}$ under different treatments

\begin{tabular}{|c|c|c|}
\hline Treatments & No. of seed Pods ${ }^{-1}$ & No. of seed Plant ${ }^{-1}$ \\
\hline $\mathbf{T}_{1}:$ Control & 8.91 & 91.33 \\
\hline $\mathrm{T}_{2}: \mathrm{Zn} \mathrm{50ppm}$ & 10.21 & 104.72 \\
\hline$T_{3}: Z n$ 100ppm & 10.62 & 108.88 \\
\hline$T_{4}: \operatorname{Zn} 150$ ppm & 10.94 & 112.13 \\
\hline$T_{5}:$ B 100 ppm & 10.18 & 104.39 \\
\hline$T_{6}:$ B 200 ppm & 10.54 & 108.08 \\
\hline$T_{7}:$ B 300 ppm & 10.66 & 113.37 \\
\hline $\mathrm{SE} \pm(\mathrm{d})$ & 0.23 & 0.26 \\
\hline CD at $(0.05 \%)$ & 0.49 & 0.57 \\
\hline
\end{tabular}

Table.11 Effect of Grain weight plant $^{-1}(\mathrm{~g})$ and 1000- seed weight $(\mathrm{g})$ under different treatments

\begin{tabular}{|c|c|c|}
\hline Treatments & Grain weight plant $^{-1}(\mathrm{~g})$ & 1000- seed weight (g) \\
\hline $\mathbf{T}_{1}:$ Control & 3.45 & 27.93 \\
\hline$T_{2}: \mathrm{Zn} \mathrm{50ppm}$ & 3.96 & 30.51 \\
\hline$T_{3}: \mathrm{Zn} \mathrm{100ppm}$ & 4.11 & 30.73 \\
\hline$T_{4}: Z n 150$ ppm & 4.24 & 30.93 \\
\hline $\mathrm{T}_{5}: \mathrm{B} 100 \mathrm{ppm}$ & 3.95 & 29.88 \\
\hline$T_{6}: B 200$ ppm & 4.08 & 30.03 \\
\hline $\mathrm{T}_{7}: \mathrm{B} 300$ ppm & 4.28 & 31.01 \\
\hline $\mathrm{SE} \pm(\mathbf{d})$ & 0.56 & 1.78 \\
\hline CD at $(0.05 \%)$ & 1.27 & 3.68 \\
\hline
\end{tabular}



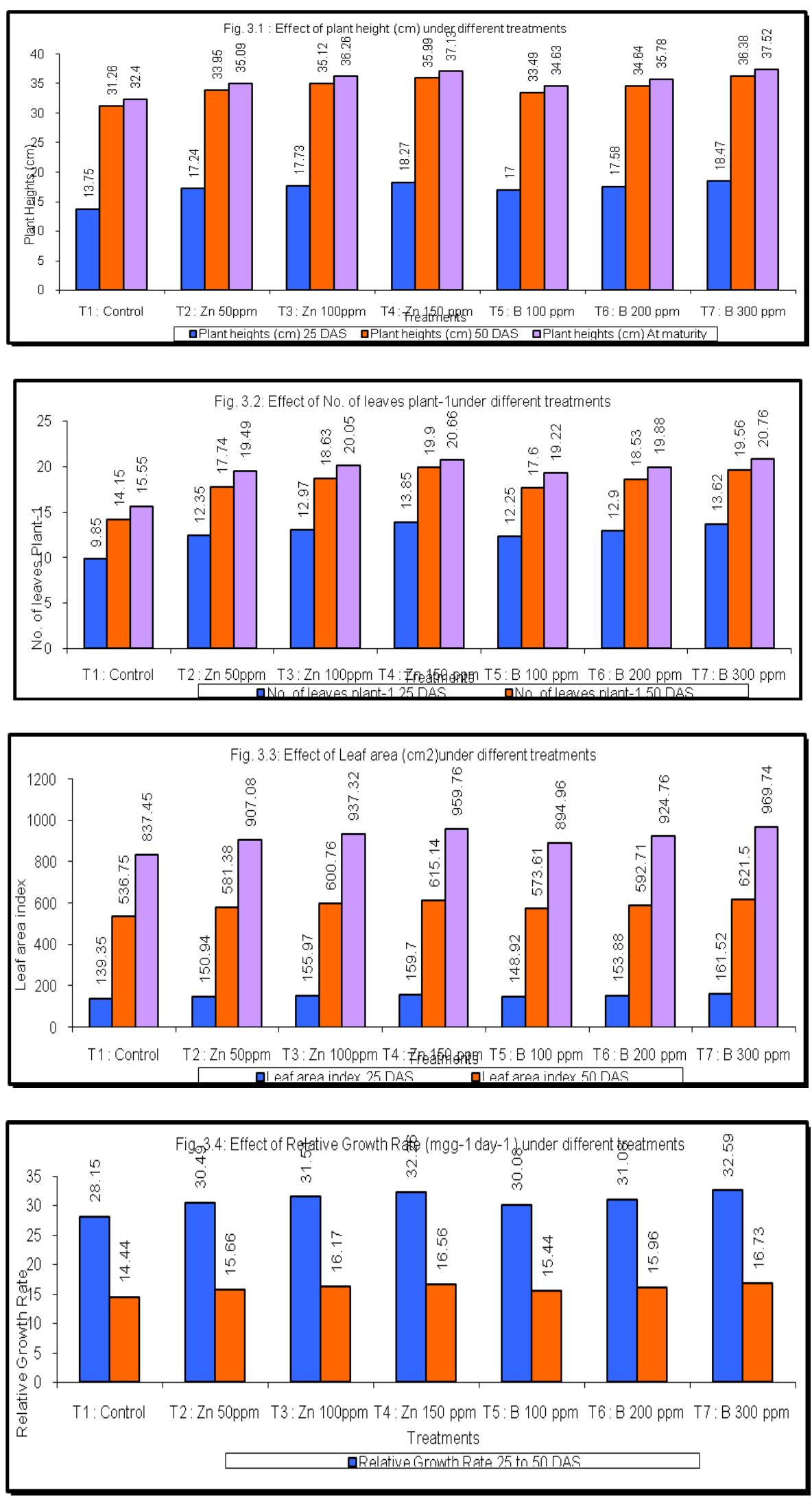

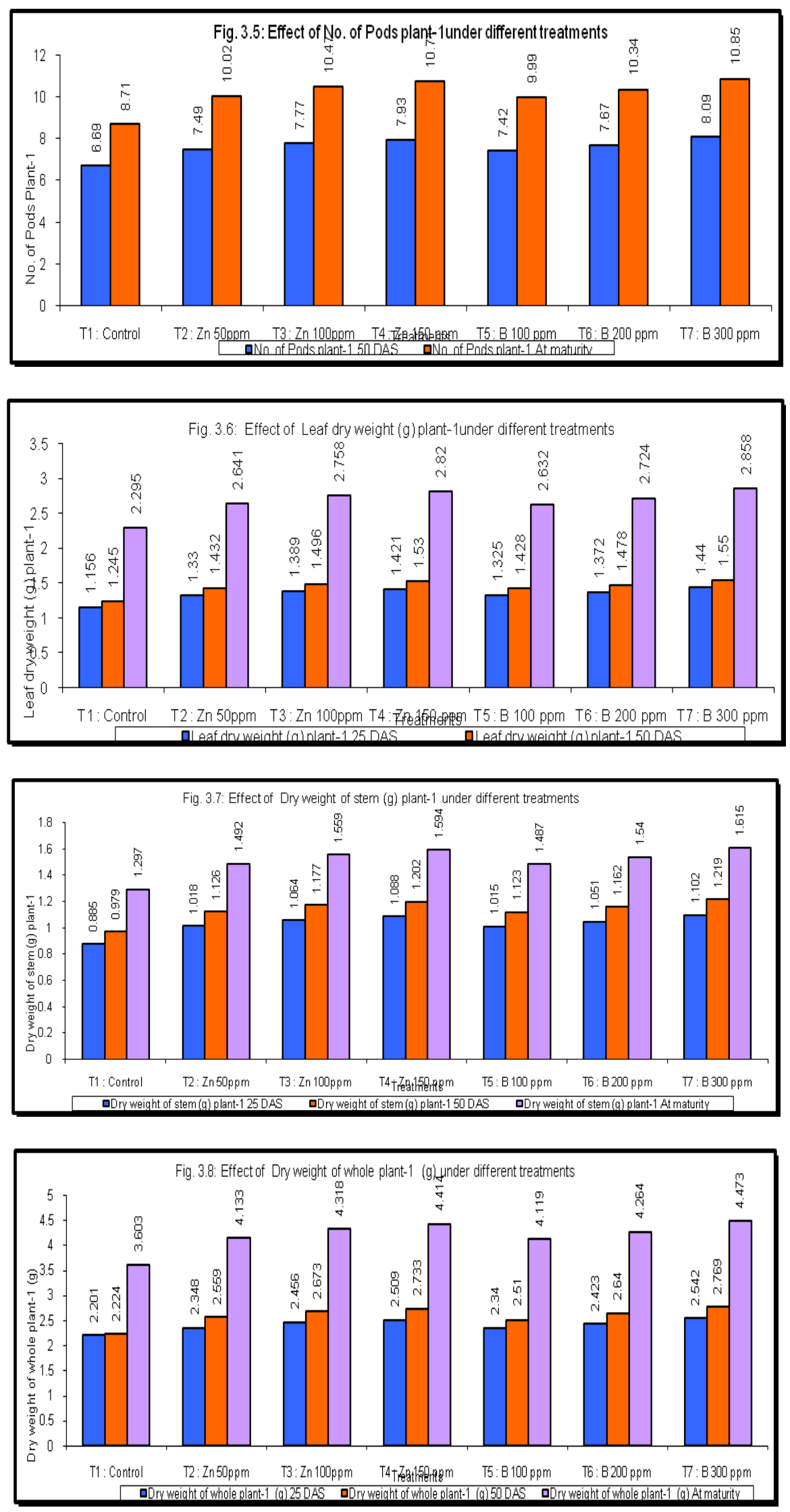

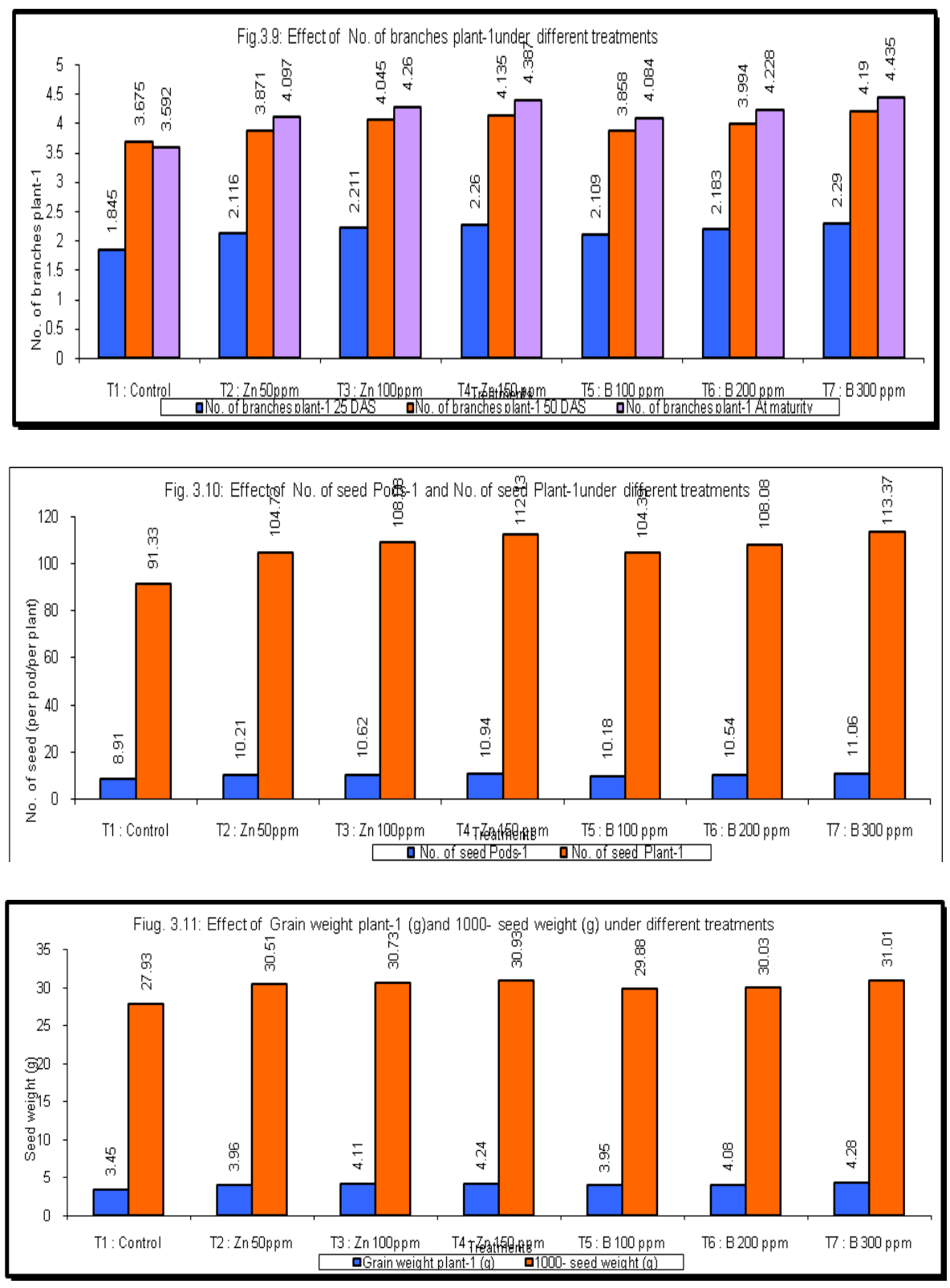

\section{Leaf dry weight (g) plant ${ }^{-1}$}

The Leaf dry weight (g) plant ${ }^{-1}$ and the result is given in Table 5, and depleted in Fig. 5. A perusal of the data indicates that leaf dry weight (g) plant ${ }^{-1}$ was substantially and significantly affected due to different treatments. Leaf dry weight $(\mathrm{g})$ plant $^{-1}$ ranged from 1.156 to $2.858(\mathrm{~g})$ in control and $\mathrm{T}_{7}$, respectively. At 25 DAS treatment B @ $300 \mathrm{ppm}$ was found to be highest leaf dry weightplant ${ }^{-1}(1.44 \mathrm{~g})$ statistically superior and at par to treatment Zn@150ppm, Zn@ 100ppm, B@200ppm, Zn@50ppm, B@ 100 ppm. Minimum leaf dry weight plant ${ }^{-1}$ was obtained in control (1.156 g). At 50 DAS treatment B @ 300ppm was found to be highest leaf dry weight $\operatorname{plant}^{-1}(1.550 \mathrm{~g})$ statistically superior and at par to treatment Zn@150ppm,Zn@100ppm, B @ 200ppm, Zn@50ppm, B @ 100ppm. Minimum leaf dry weight plant ${ }^{-1}$ was obtained in control 
(1.245 g). At Maturity treatment B @ 300ppm was found to be highest leaf dry weight plant ${ }^{1}(2.858 \mathrm{~g})$ statistically superior and at par to treatment Zn@150ppm, Zn @ 100ppm, B @ 200ppm, Zn@50ppm, B @ 100ppm. Minimum leaf dry weight plant ${ }^{-1}$ was obtained in control (2.295 g) (Saha et al., 1996; Gowthami et al., 2014)

\section{Dry weight of stem (g) plant ${ }^{-1}$}

The Dry weight of stem (g) plant ${ }^{-1}$ and the result is given in Table 6, and depleted in Fig. 6. A perusal of the data indicates that dry weight of stem (g) plant $^{-1}$ was substantially and significantly affected due to different treatments. Dry weight of stem (g) plant ${ }^{1}$ ranged from 0.885 to $1.615(\mathrm{~g})$ in control and $\mathrm{T}_{7}$, respectively. At 25 DAS treatment B @ $300 \mathrm{ppm}$ was found to be highest stem dry weight plant $^{-1}(1.102 \mathrm{~g})$ statistically superior and at par to treatment Zn @ 150ppm, Zn@ 100ppm, B@ @200ppm, Zn @ 50ppm, B @ 100ppm. Minimum stem dry weight plant ${ }^{1}$ was obtained in control $(0.885 \mathrm{~g})$. At 50 DAS treatment B @ 300ppm was found to be highest stem dry weight $\operatorname{plant}^{-1}(1.219 \mathrm{~g})$ statistically superior and at par to treatment Zn@150ppm, Zn @ 100ppm, B @ 200ppm, Zn@50ppm, B @ 100ppm. Minimum stem dry weight plant ${ }^{-1}$ was obtained in control (0.979 g). At Maturity treatment B @ 300ppm was found to be highest stem dry weight plant $^{-1}(1.615 \mathrm{~g})$ statistically superior and at par to treatment Zn @ 150ppm, Zn @ 100ppm, B @ 200ppm, Zn @ 50ppm, B @ 100ppm. Minimum stem dry weight plant $^{-1}$ was obtained in control (1.297 g) (Novoselova et al., 1977; Valenciano et al., 2001; Chatterjee et al., 2015).

\section{Dry weight of whole plant ${ }^{-1}(g)$}

The Dry weight of whole plant ${ }^{-1}(\mathrm{~g})$ and the result is given in Table 7 and depleted in Fig. 3.7. It is evident from the data that dry weight of whole plant $^{-1}(\mathrm{~g})$ ranged from 2.201 to $4.473 \mathrm{~g}$ under different treatments. The minimum and maximum values were obtained from control and treatment of $\mathrm{T}_{7}$ which received B @ 300ppm. Furthermore, it is apparent heal their seeds were obtained with higher doses of $\mathrm{Zn}$ foliar application as compared to control. Therefore, it was found significantly in increasing trend, more precisely 4.414 percent in treatment of $\mathrm{T}_{4}$. At 25 DAS treatment B @ 300ppm was found to be highest whole dry weight plant ${ }^{-1}(2.542 \mathrm{~g})$ statistically superior and at par to treatment Zn@150ppm, Zn@100ppm, B @ 200ppm, Zn@50ppm, B @ 100ppm. Minimum whole dry weight plant $^{-1}$ was obtained in control (2.201 g). At 50 DAS treatment B @ 300ppm was found to be highest whole dry weight $\operatorname{plant}^{-1}(2.769 \mathrm{~g})$ statistically superior and at par to treatment Zn @ 150ppm, Zn @ 100ppm, B @ 200ppm, Zn @ 50ppm, B @ 100ppm. Minimum whole dry weight plant ${ }^{-}$ ${ }^{1}$ was obtained in control $(2.224 \mathrm{~g})$. At Maturity treatment B @ 300ppm was found to be highest whole dry weight plant $^{-1}$ (4.473 g) statistically superior and at par to treatment Zn@150ppm, Zn@100ppm, B @ 200ppm, Zn@ @0ppm, B @ 100ppm. Minimum whole dry weight plant ${ }^{-1}$ was obtained in control (3.603 g) (Bellaloui et al., 2009).

\section{No. of branches plant ${ }^{-1}$}

The No. of branches plant ${ }^{-1}$ and the result is given in Table 8 and depleted in Fig. 8. It was observed that increasing levels of foliar application significantly influenced the No. of branches plant ${ }^{-1}$. Successive increase in different doses of foliar application treatments significantly enhanced the No. of branches plant $^{-1}$. The treatment $T_{7}$ is getting B @ $300 \mathrm{ppm}$. The corresponding lowest values were obtained under control. At 25 DAS treatment B @ 300ppm was found to be highest no of branches $\operatorname{plant}^{-1}(2.290)$ statistically superior and at par to treatment 
Zn@150ppm,Zn@100ppm, B @ 200ppm, Zn@50ppm, B @ 100ppm. Minimum no of branches plant ${ }^{-1}$ was obtained in control (1.845). At 50 DAS treatment B @ 300ppm was found to be highest no of branches plant ${ }^{1}(4.190)$ statistically superior and at par to treatment Zn @150ppm, Zn @ 100ppm, B @ 200ppm,Zn@50ppm followed by B @ $100 \mathrm{ppm}$. Minimum no of branches plant ${ }^{-1}$ was obtained in control (3.675). At Maturity treatment B@300ppm was found to be highest no of branches $\operatorname{plant}^{-1}(4.435)$ statistically superior and at par to treatment Zn@150ppm,Zn @ 100ppm, B @ 200ppm, Zn@50ppm, B @ 100ppm. Minimum no of branches plant ${ }^{-1}$ was obtained in control (3.592) (Singh, 2012a; Singh et al., 2014; Alam et al., 2017).

\section{No. of Pods plant ${ }^{-1}$}

The number of pods plant ${ }^{-1}$ and the result is given in Table 9, and depleted in Fig. 9. The scrutiny of the data clearly indicates that number of pods plant ${ }^{-1}$ occurred in between 50 and at maturity days after sowing. Significant variations were observed under different treatments. Simultaneously, number of pods plant ${ }^{1}$ maximum treatment of $\mathrm{T}_{7}$ when B @ 300ppm was applied as compared to control. Similarly, $\mathrm{Zn}$ were observed in between 50 DAS to at maturity lowest $\mathrm{T}_{1}$ : Control and highest values being under control and $T_{7}$ respectively. At 50 DAS treatment B @ 300ppm was found to be highest No of pod plant ${ }^{-1}$ (8.09) statistically superior and at par to treatment $\mathrm{Zn} @ 150 \mathrm{ppm}$, Zn @ 100ppm,B @ 200ppm, Zn @ 50ppm, B @ 100ppm. Minimum no of pod plant ${ }^{-1}$ was obtained in control (6.69). At maturity treatment B @ 300ppm was found to be highest No of pod plant ${ }^{-1}(10.85)$ statistically superior and at par to treatment Zn @ 150ppm, Zn @ 100ppm, B @ 200ppm, Zn @ 50ppm, B @ 100ppm. Minimum no of pod plant ${ }^{-1}$ was obtained in control (8.71) (Balachander et al., 2003; Shil et al., 2007; Quddus et al., 2012).

\section{No. of seed Pods ${ }^{-1}$ and No. of seed Plant ${ }^{-1}$}

The No. of seed pods ${ }^{-1}$ and No. of seed Plant ${ }^{-1}$ and the result is given in Table 10 and depleted in Fig. 10. A critical review of the data showed that the different mungbean treatments under the test differ significantly in No. of seed pods ${ }^{-1}$. The maximum No. of seed pods $^{-1}$ was observed in treatment of $\mathrm{T}_{7}$ : B @ $300 \mathrm{ppm}$ (11.06) followed by treatments of $\mathrm{T}_{4}$ : Zn @ 150ppm (10.94) and it was latest in treatment of $\mathrm{T}_{1}$ : Control (8.91). In respect of No. of seed Plant ${ }^{-1} \mathrm{M}_{1}$ : Without mulch was observed significantly maximum No. of seed Plant $^{-1}$ (113.37) followed by $\mathrm{T}_{7}$ : B @ 300ppm and was latest with the $\mathrm{T}_{1}$ : Control (91.33) during the experimentation. No of Seed Pods ${ }^{1}$ treatment B @ 300ppm was found to be maximum no of seed pods ${ }^{-1}$ (10.66) statistically superior and at par to treatment Zn@150ppm, Zn @ 100ppm followed by B @200ppm,Zn@50ppm, B @ 100ppm. Minimum no of seed pods ${ }^{-1}$ was obtained in control (8.91). No of seed Plant ${ }^{-1}$ treatment B @ 300ppm was found to be maximum no of seed Plant ${ }^{-1}(113.37)$ statistically superior and followed by treatment Zn @ 150ppm, Zn @ 100ppm, B@200ppm,Zn@50ppm, B @ 100ppm. Minimum no of seed Plant ${ }^{-1}$ was obtained in control (91.33) (Chakraborty, 2005).

\section{Grain weight plant $^{-1}(\mathrm{~g})$ and 1000 - seed weight $(g)$}

The Grain weight plant ${ }^{-1}(\mathrm{~g})$ and 1000- seed weight $(\mathrm{g})$ and the result is given in Table 11 and depleted in Fig. 11. A critical review of the data showed that the different mungbean treatments under the test differ significantly in Grain weight plant ${ }^{-1}(\mathrm{~g})$. The maximum Grain weight plant $^{-1}(\mathrm{~g})$ was observed in treatment of $\mathrm{T}_{7}$ : B @ 300ppm (4.28) followed by treatments of $\mathrm{T}_{4}: \mathrm{Zn} @ 150 \mathrm{ppm}$ (4.24) and it was latest in treatment of $\mathrm{T}_{1}$ : Control (3.45). It is evident from the data that 1000 seed 
weight ranged from 27.93 to $31.01 \mathrm{~g}$ under different treatments. The minimum and maximum values were obtained from control and treatment of $\mathrm{T}_{7}$ which received $\mathrm{B}$ @ 300ppm (Bharti et al., 2002).

Grain weight plant $^{-1}$ (g)treatment B @ 300ppm was found to be highest grain weight plant ${ }^{1}$ (4.28) statistically superior and at par to treatment Zn@150ppm,Zn@100ppm, B @ 200ppm, Zn @ 50ppm, B @ 100ppm. Lowest grain weight plant $^{-1}$ was obtained in control (3.45) (Konthoujam et al., 2009), Mondal et al., 2012).

Test Weight or Weight of 1000 seed treatment B @ 300ppm was found to be highest test weight (31.01) statistically superior and at par to treatment Zn @ 150ppm, Zn @ 100ppm, B @ 200ppm, Zn @ 50ppm, B @ 100ppm. Lowest test weight was obtained in control (27.93) (Mondal et al., 2005; Rahman et al., 2005).

It can be concluded that foliar application of boron@300ppm incorporated as foliar application have fetched highest plant height, higher no of branches plant ${ }^{-1}$ higher no leaf plant $^{-1}$, higher leaf area index plant ${ }^{-1}$, maximum dry matter production plant $^{-1}(\mathrm{~g})$, maximum value of RGR (mg/g/day) plant $^{-1}$, high no of pod plant ${ }^{-1}$ high no of seed plant $^{-1}$, maximum seed weight $(\mathrm{g})$ plant $^{-1}$, maximum value of 1000 seed weight (g) for higher productivity along with seed production.

\section{References}

Alam, M. S., Ali, K. J. and Hoque, A. (2017). Yield and yield component of chickpea as affected by boron application. Journal of Experimental Agriculture International, 15(2): 1-9.

Balachander, D., Nagarjan, P. and Gunasekharan, S. (2003). Effect of micronutrient on nodulation and yield of black gram in acid soil condition. Legume Research, 26(2): 153-154.

Bellaloui, N., Abbas, H.K., Gilten, A.M. and Abel, C.A. (2009). Effect of glyphosate and boron application on seed composition and nitrogen metabolism in glyphosate resistant soybean. Agri and food chemist, 57 (19): 950-956.

Bharti, N.; Murtaza, M. and Singh, A.P. (2002).Effect of boron-rhizobium relationship on yield, nitrogen and boron nutriation of chickpea. J. Res. BirsaAgril. Univ., 14(2): 175-179.

Chakraborty, A. (2005). Growth and yield a lentil (Len culinaris L.) as affected by boron and molybdenum application in lateritic soil. Journal of Crop and Weed, 5 (1): 96-99.

Chatterjee, R. and Bandyopadhyay, S. (2015). Effect of boron, molybdenum and bio fertilizers on growth and yield of cowpea (Vigna unguiculata L. Walp.) in acid soil of eastern Himalayan region. $J$. Saudi. Soci. Agric. Sci.,http://dx.doi.org/10.1016/j.jssas.201 5.11.00.

Gowthami P. and Rao, G. Rama (2014). Effect of foliar application of potassium, boron and zinc on growth analysis and seed yield in soybean. Int. J. Food, Agric. Vet. Sci., 4(3): 73-80.

Konthoujam, N.D., Laikhanjbam, N.K.S., Maibam, S.S., Soibam, B.S. and Keisham, K.S. (2009). Influence of Sulphur and boron fertilization on yield, quality, nutrient uptake and economics of soybean (Glycine max). under upland conditions. Journal of Agriculture Sciences, 4 (4): 192-194.

Mondal, C., Bandopadhyay, P., Alipatra, A., Banerjee (2012).Performance of summer mung bean (Vigna radiata L. Wilczeck) under different irrigation regimes and boron levels. Journal of Food Legume, 25 (1): 7-40.

Mondal, D., Bhattacharya, S.S. and 
Chattopadhyay, G.N. (2005). Nutrient Management of red and lateritic soils for increasing the productivity of urdbean. Indian Journal of Pulse Research, 18: 86-87.

Novoselova, A.S. and Ryabov, A.A. (1977).Effect of boron and zinc on seed yield of tetraploid Red clove. Sbornik Nauchnykh Raboot, Vsesoyuznyi Nauchnoissle-dovatel Skiinstitrt Kormov. 16:140-144.

Patra, P.K., Bhattacharya, C. (2009). Effect of different level of boron andmolybdenum on growth and yield of mung bean (Vigna radiata(L.) Wilzeck) cv. Baisakhi Mung in red and lateritic zone of West Bengal. Journal of Crop and Weed, 5 (1): 199-201.

Quddus, M.A., Rashid, M.H., Hossain, M.A., Naser, H.M. and Main, J.A. (2012). Integrated nutrient management of sustaining soil fertility through chickpea mung bean, $T$. aman cropping pattern at Madaripur, Bangladesh Journal of Agricultural Research, 37(2): 251-262.

Rahman, M., Imran, M., Ashraf and Urzaman, M., (2012). Effect of inoculant on yield and yield contributing characters of summer mung bean cultivars. Journal of environmental Sciences Natural Resources, 5 (1): 211-215.

Saha, A., Mandal, B.K. and Mukhopadhyay, P. (1996). Residual effect of boron and zinc on the yield of succeeding mungbean in summer. Indian Agriculturist. 40 (1): 11-16.

Salinas, R.M., Caro, M., Cerda, A. and Santa,
C.F. (1985).The interaction effect of B and $\mathrm{Zn}$ on pea growth. Anales de Edafolgia Y. Agrobiologia. 44(11-12): 1727-1733.

Shamsuddoha, A.T.M., Anisuzzaman, M., Sutradhar, G.N.C., Hakim, M.A. and Bhuiyan, M.S.I. (2011). Effect of Sulphur and boron on nutrients in mungbean (Vigana radiata L.). IJBSM., 2(2): 224-229.

Shil, N.C., Noor, S. and Hossain, M.A. (2007). Effect of boron and Molybdenum on the yield of chickpea. Journal of Agriculture and Rural development 5 (1\&2): 17-24.

Singh, D. K., Singh, A. K., Singh, M., Bordoloi, L.J. and Srivastava, O. P. (2012a). Production potential and nutrient uptake efficiency of pea (Pisum sativum L.) as influenced by different fertility levels and micronutrients. $J$. Indian Society Soil Sci., 60(2): 150-155. Singh, D. K., Singh, A. K., Singh, M., Jamir, Z. and Srivastava, O.P. (2014). Effect of fertility levels and micronutrients on growth, nodulation, yield and nutrient uptake by pea (Pisum sativum L).Legume Res., 37(1): 93 - 97.

Valenciano, J.B., Boto J.A. and Marcelo V., (2001).Chickpea (Cicer arietinum L.) response to zinc, boron and molybdenum application under field conditions. New Zealand Journal of Crop and Horticultural Science, 39:4, 217-229, DOI: 10.1080/01140671.2011.577079.

\section{How to cite this article:}

Narendra Pratap Verma, M. A. Khan, Pradip Kumar Saini, Virendra Pratap Verma and Shraddha Singh. 2020. Effect of Foliar Application of Zinc and Boron on Growth and Yield of Mungbean (wilczek) (Vigna radiata L.). Int.J.Curr.Microbiol.App.Sci. 9(10): 3691-3704. doi: https://doi.org/10.20546/ijcmas.2020.910.426 